\title{
Turning teaching inside out
}

\section{Julia Ostertag}

\section{Introduction}

In the weeks preceding a 2010 summer course taught by Madeleine Grumet, I began reading Bitter Milk, Places of Learning, The Beast in the Nursery, and, finally as a "treat", Housekeeping. I read while breastfeeding, while walking through Pacific Spirit Regional Park with my then six-month-old son Olivier in the stroller or in a carrier on my chest, and during those all-too-short quiet moments when Olivier napped or my partner took him for a walk. Bitter Milk I loved, Beast in the Nursery frustrated me, Places of Learning spoke a familiar language but within unfamiliar contexts, and Housekeeping haunted and intrigued. It was on one of those walks where I read Place of Learning while pushing Olivier in the stroller that I experienced that "frisson" (de Bolla, 2001, p. 2 in Ellsworth, 2005, p. 24) of "knowledge in the making" (Ellsworth, 2005, p. 1). Although Places of Learning recognizes the value of experiences of place in pedagogy, it omits the large body of ecological, experiential, and social justice education work on developing place-based education (E.g.: Gruenewald \& Smith, 2009) to address human and more-than-human relationships (Abram, 1996). Since these areas are the pedagogical approaches that speak most to me, I could not help but wonder how Ellsworth's ideas might relate to some of my own work. One of my projects as a graduate student at UBC's Faculty of Education has been to research the possibilities for an outdoor classroom for teacher education; however, I had begun to lose 'interest' (Phillips, 1998) in that dream. 
Translating conceptual complexity into reality in the physical realm seemed to suck the dynamism out of my vision. Places of Learning, with its exploration of sensation, movement, our bodies' experiences of place, and performance suggested a different path for reconceptualizing outdoor classrooms. So, on April 21, I sat down on a cedar stump and began sketching and imagining an outdoor classroom anew by playing with the concepts and experiences of inside and outside, without trying to design a space that would act as a model or blueprint (Ellsworth, 2005, p. 9). At the risk of being too literal, in this paper I will explore how outdoor classrooms can challenge and reconfigure teaching and learning relationships by considering the significance of "inside" and "outside" in pedagogy.

\section{Outdoor classrooms: Leading out, finding home}

Schooling, according to Grumet (1988), provides "a passage from domestic and maternal nurturance to public institutions and patriarchal identifications" (p. 33). I find it unsurprising, therefore, that schooling - with its rejection of the sensuous experiences of home - has 'led students out' profoundly alienated from the natural world. It is through the embodied experience of living and learning at home (ecology means house knowledge), however, with which I would like to pry open the doors of the classroom so that we can aesthetically experience home throughout our experiences of school. Outdoor classrooms may create a pedagogical hinge where "inside and outside [are put] into relation" (Ellsworth, 2005, p. 46 author's emphasis) and transitional, liminal pedagogical spaces are re-imagined and explored that challenge and celebrate our human-nature relationships. 
Outdoor classrooms - or schools more generally - are difficult spaces to reimagine. As Grumet (1988) reminds us, we can erase the vestiges of

the male curriculum, banking education, the process/product paradigm, the myth of objectivity. We can give the old furniture away to Goodwill or domesticate it, turning old school desks into planters and telephone tables. We can silence the clanging lockers, period bells, 'now-hear-this' loudspeakers. We can make it a demilitarized zone. But still we are not in an empty space. (p. 186)

The word classroom brings with it all the baggage of teacher-centred, teacher-controlled learning of knowledge made, not experienced "in the making" (Ellsworth, 2005) with our entire beings and within wider communities of beings. For instance, when I talk with UBC's landscape architects about outdoor classrooms, their vision is generally focused on passive learning in amphitheatre-like spaces, which focus learners' gazes on the omnipotent expert standing front and centre. My vision tends more toward garden-based education and its hands-on, hands-in-dirt, bellies-filling-with-food approaches to learning and being in place.

Gardens are highly participatory spaces, where inside and outside, culture and nature are blurred. As transitional spaces, they can bring learning selves in relationship with the broader cultural and natural communities within which we are constantly, yet largely blindly, moving. According to Winnicott:

transitional space is what makes possible the difficult transition from a state of habitual ('natural' feeling) compliance with the outside world, with its expectations, traditions, structures, and knowledges, to a state of creatively putting those expectations, traditions, and structures to new uses. In Winnicott's view, this event of inner transition is made possible only when we dare to move into relation with the outside world of things, other people, environments, and events.... Winnicott called this movement the never-ending work and play of keeping inside and outside both interrelated and separate. (Ellsworth, 2005, p. 30) 
My experiences of schooling, however, make it all-too clear that our discussions and experiences of inside/outside value inner intellectual development within four walls, and subordinate sensuous, participatory experiences of place as privileged add-ons to the curriculum. This bias in our approaches to pedagogy is not recent. For instance, Abram (1996) refers to Socrates' disinterest in the country: "You must forgive me, dear friend. I'm a lover of learning, and trees and open country won't teach me anything, whereas men in the town do" (p. 116). The implications of this statement are manifold. Abram argues that " $[\mathrm{t}] \mathrm{o}$ define the phenomenon as an inert object, to deny the ability of a tree to inform and even instruct one's awareness, is to have turned one's senses away from that phenomenon. It is to ponder the tree from outside of its world, or, rather, from outside of the world in which both oneself and the tree are active participants" (p. 117). He compares this with indigenous, oral cultures, where "nature itself is articulate; it speaks. The human voice in an oral culture is always to some extent participant with the voices of wolves, wind, and waves - participant, that is, with the encompassing discourse of an animate earth" (p. 116-117).

Abram (1996), in The Spell of the Sensuous, explores the relationships between language, place, and awareness. As such, his book provides the ecological counterpoint to Ellsworth's (2005) Places of Learning, which focuses entirely on the world as constructed through human hands. Ellsworth's "new pedagogies of sensation" (p. 27) include

those 'immediate somatic responses,' those 'frissons of physical encounter,' and those 'somethings' that are 'more elemental than a process of intellectualization' (de Bolla, 2001, p. 2). Pedagogy is seldom engaged as an event in which the materiality of a time and place of learning impinges on the materiality of the learning self understood as a 'processual engagement of duration and movement, articulated through 
webs of sensation across landscapes and panoramas of space, bodies, and time' (Kennedy, 2003, p. 4) and educational materials (Ellsworth, 2005, p. 24).

Similar to Ellsworth, Abram also describes this "frisson" of relating with the world through webs of sensations phenomenologically; however, his considerations arise from his personal experiences as a magician and anthropologist interested in shamanic medicine and magic. Accordingly, Abram describes the processual engagement of a shaman as

the ability to readily slip out of the perceptual boundaries that demarcate his or her particular culture - boundaries reinforced by social customs, taboos, and most importantly, common speech or language - in order to make contact with, and learn from, the other powers in the land. His magic is precisely this heightened receptivity to the meaningful solicitations songs, cries, gestures - of the larger, more-than-human field. (p. 9)

If the doors and windows of schools opened to allow more movement into these vibrant conversations, our curriculum may point children toward relationships with home that are filled with vitality and possibility, rather than a world of destruction and exploitation.

Considering outdoor classrooms as transitional spaces on our passage home requires carefully rethinking our relationship with home as a place and idea. In our industrial, urban, and patriarchal society, home is perceived as a low-status a place of confinement, tradition, women's labour, parochialism, and slowness compared with life in the public world. In Housekeeping, Robinson (1988) tears apart this static and oppressive notion of home and infuses it with movement, freedom, and nature without jeopardizing the importance of kinship: "When one looks from the darkness into the light, however, one sees all the difference between here and there, this and that. Perhaps all unsheltered people are angry in their hearts, and would like to break the roof, spine, and ribs, and smash the windows and flood the floor and spindle the curtains and bloat the 
couch" (Robinson, 1980, p. 158). Ruth, the story's narrator, is aware of the parallels between the ways in which we inhabit houses and our bodies. Despairing that Sylvie her ersatz mother - will not return, Ruth thinks, "Let them come unhouse me of this flesh, and pry this house apart" (p. 159). Furthermore, as Ruth's relationship with Sylvie is threatened and she fears that her family will be torn apart, she considers that, "A house should have a compass and a keel" (p. 184). As these passages suggest, home is a dynamic relationship between kin based on resting and moving, idea and experience, continuity and change. Moreover, it is open to the ever-pervasive presence and power of place. Through Sylvie's approach to housekeeping, the family home in Fingerbone is opening to natural world and its rhythms:

I noticed that the leaves would be lifted up by something that came before the wind, they would tack against some impalpable movement of air several seconds before the wind was heard in the trees. Thus finely did our house become attuned to the orchard and to the particularities of weather, even in the first days of Sylvie's housekeeping. (p. 85)

What are the implications for outdoor classrooms when they are home-like, hence embedded in ecologies of place, yet permeable and open to change? I will suggest that participation, play, and performance are important design elements for outdoor classrooms that provide "opportunities for us to both act in the world and to be acted upon it" (Ellsworth, p. 32) without creating a prescriptive curriculum that would undermine the generations of unlearning and reschooling that will be required to transform our pedagogies of sensation.

\section{Design: Participation and performance}

In the following section, I will consider the design elements that could inform a re-imagining process for creating an outdoor classroom at the Faculty of Education, 
UBC. My particular interest is in the pedagogical possibilities that designing, learning, and teaching in an outdoor classroom can have for teacher education, particularly since a lack of teacher training has been identified as a significant barrier in the expansion of school gardens and outdoor classrooms (e.g.: Blair, 2009; Desmond, Grieshop, \& Subramaniam, 2004; Dyment, 2005; Gaylie, 2009). Teacher education provides a brief moment for student teachers to challenge themselves and deschool at least 15 years of teaching and learning experience that have taken place inside. As Veronica Gaylie (2009) discovered in her learning garden for middle school teacher education students, teaching and learning outside profoundly disrupts our hierarchical conceptions of the roles and identities of students and teachers. According to Gaylie (2009), one of the reasons why school gardens remain marginal is that garden-based education's potential to influence student learning is underestimated, perhaps because "gardens are predominantly viewed as little more than a teaching tool that transmits curriculum in standard methods of instruction" (p. 32). Access to an outdoor classroom can provide teacher education students with the opportunity to explore pedagogy and curriculum across the disciplines. In this "good-enough holding environment" (Ellsworth, 2005, p. 32), "[t]eachers, understood as being in the making themselves, would necessarily have to create places of learning in embodied terms and in ways that depart from the dominant perception as the acquisition of knowledge driven by cognitive functions" (Ellsworth, 2005, p. 28). Therefore, in response to Winnicott's question regarding design principles - "What kind of environment (what means and conditions, what pedagogies) best invite and support the constant movement of putting in relation that transforms the person one has been into the person will become?" (Winnicott cited in Ellsworth, 2005, p. 61), I propose that 
participation and performance are powerful conditions for re-imagining the good-enough holding environment of an outdoor classroom.

Before embarking on a discussion of these elements, however, I would like to expand on a few ideas associated with outdoor classrooms. As I stated earlier, my interpretation of outdoor classrooms is largely influenced by my interest in growing gardens, particularly food gardens. While it is attractive to view gardens as teachers (See: Gaylie, 2009), I remain cautious in ascribing value-free agency to these types of outdoor classroom. Especially gardens, since as a form of 'agriculture', these spaces are liminal areas that are "partly human, partly more than human" (Weston, 1994, p. 123). For instance, one of the areas that I would like to research further are the use of gardens and agriculture in assimilating First Nations peoples to sedentary European lifestyles through the residential school system:

Necessity may compel the adult Indian to take up the spade and submit to manual labour, but a child brought up in the love of cultivating a garden will be naturally led to the culture of the field as a means of subsistence: and educated in the principle of Christianity, he will become stationary to partake of the advantages and privileges of civilization. It is through these means of instruction that a change will be gradually effected in the character of the North American Indian. (cited in Miller, 1996, pp. 69-70)

This historical reference to the use of gardens in education, however, is only one of many, since school gardens and outdoor classrooms have figured in Western pedagogical theory and school design since Comenius, Rousseau, Pestallozzi, Froebel, Dewey, and Montessori (Subramanian, 2002; Gaylie, 2009). Currently, however, outdoor classrooms are considered to be spaces designed for experiential learning across the disciplines, often including gardens, schoolyard naturalization projects, and public art. While I consider it important to remember that the entire world is a "classroom," outdoor classrooms provide 
an accessible and participatory space for exploration and sustained engagement. It is in this sense of sustained engagement that I believe that outdoor classrooms - particularly garden-based outdoor classrooms - differ from, for example, outdoor environmental education centres. Sustained engagement, rather than exoticized adventure, provides the experiential pathways that can build bridges between inner and outer worlds, and values the sensuous, embodied potential of our minds/bodies to engage with the world and ourselves.

First and foremost, since I would like to avoid the trap of designing a "one-sizefits-all" model of an outdoor classroom, it is important that the design process is not only participatory but also embedded in place. Truly designing an outdoor classroom to be an expression of a conversation with place will take generations, or be a never-ending project. However, a close attunement to the land throughout the various seasons, times of day, changing weather, etc. is a necessary starting point.

Designing a classroom in conversation with place is a participatory learning experience in itself. Through design charrettes (Ellsworth, 2005), student teachers, professors, and other community members can become actively engaged in this reimagining process. This process will teach how, for example, "[a] particular place in the land is never, for an oral culture, just a passive or inert setting for the human events that occur there. It is an active participant in those occurrences. Indeed, by virtue of its underlying and enveloping presence, the place may even be felt to be the source, the primary power that expresses itself through the various events that unfold there" (Abram, 1996, p. 162). Participating in the design process, however, is still the first step.

Participating in place, as Abram describes above, is where designing and learning blur. In 
my personal vision, I see this participation taking place through, for instance, intergenerational and intercultural gardening activities, public art installations, crossdisciplinary research projects, and performances. While environmental education across the curriculum may be an element of much of the teaching and learning that takes place in the outdoor classroom, the space itself will be moved from backdrop to foreground (inside to outside) in the learning experience.

It was Ellsworth's emphasis on the importance of movement and performance that challenged me to first consider the outdoor classroom as something other than a garden project that could serve as a model for student teachers to replicate in their future schoolyards:

sensations of ideas being made futile by the environment surrounding them; sensations of being 'in motion'; sensations of time and space, finely timed rhythms, and heightened mind-body connections; sensations of drama and of being 'drawn through'; senses of wonder, of bypassed memory and cognition; awareness of self-change; and full body involvement. (Ellsworth, 2005, p. 22)

Playing with the ideas of contradiction and movement, I appreciated Ellsworth's insights that pedagogical spaces express "a concern with setting the view, learner, or audience in motion across boundaries between inside and outside, not with the intent to define or reinforce those boundaries but to forge participation in the times and spaces of relationality between inside and outside" (Ellsworth, 2005, p. 46). Some of the design ideas I have been sketching and playing with include: doorways and windows leading "in" and "out" of the classroom; "exit" and "enter" signs as you enter and exit the classroom; a tool shed built of high school lockers and chalkboards; planters built of school desks (I had to laugh when I read that line in Bitter Milk, since I thought my idea was so original at the time!); a bell hanging from the maple tree; etc. Playing with our 
preconceived notions of what constitutes a classroom in an outdoor setting reminds us that the world is a classroom; that our perceptions and habits construct what we value as knowledge. Only thinking of the potential gardening projects (e.g. native plants, local First Nations agriculture, gardens from around the world, gardens inspired by literature) that could take place in the outdoor classroom was interesting but it was not original. Playfully performing an outdoor classroom, however, filled me with "a sense of aliveness [that] a person needs a capacity to access the world around her and then to use it creatively and responsibly rather than simply to comply with it" (Ellsworth, 2005, p. 59). In particular, the serpentine pathway that already meanders through the potential outdoor classroom space (See map above) is a design element that inspired many ideas for movement and performance. For example, I can imagine working with teacher education students in the fine arts program and designing temporary installations on or along this "experiential pathway" (Ellsworth, 2005, p. 85), providing the space for "sensations of being somewhere in between thinking and feeling, of being in motion through the space and time between knowing and not knowing, in the space and time of learning as a lived experience with an open, unforeseeable future" (Ellsworth, 2005, p. 17). Ellsworth and most environmental educators recognize the central importance of a sense of wonder in learning experiences; participation and performance are ways of being in place that can certainly lead to a sense of wonder.

\section{Conclusion}

Education is a contradictory act (Grumet, 1988); we teach toward that which is already passed, for that which we long but cannot attain. For me personally, this longing 
is for an education that fosters an attunement and relationship with the more-than-human world. There are people on this planet who have learned to listen and speak with the natural world, though their lives, languages, and landscapes are increasingly threatened. Recently, I listened to Wade Davis speak on the radio (Ideas, The Massey Lectures, CBC, March 30, 2010) about wayfinders, the traditional navigators of the seafaring Polynesians. Hearing Davis speak about how navigators can hold the image of where they are going and where they are coming from in their minds for thousands of kilometres across open water by maintaining an unfathomable attentiveness to wind, waves, currents, light, bird, fish, stars, and smells attests to the potential of our minds/bodies to engage with the outside world. Yet for most people, these more-thanhuman conversations remain silenced, leaving me feeling gypped about how our learning selves have been stilted by our approaches to learning in modern western schools. It is my hope that embodied, sensual ways of knowing - for myself, my children, all people can be explored through the simple, small-scale act of teaching and learning in outdoor classrooms 


\section{References}

Abram, D. (1996). The spell of the sensuous. New York: Vintage Books.

Blair, D. (2009). The child in the garden: An evaluative review of the benefits of school gardening. Journal of Environmental Education, 40(2), 15-38.

Desmond, D., Grieshop, J. \& Subramaniam, A. (2004). Revisiting garden-based learning in basic education. Retrieved from United Nations Educational, Scientific and Cultural Organization - International Institute for Educational Planning www.unesco.org/iiep

Dyment, J. (2005). Gaining Ground: The power and potential of school ground greening in the Toronto District School Board. Toyota Evergreen Learning Grounds Program. http://www.evergreen.ca/en/lg/lg-resources.html

Ellsworth, E. (2005). Places of learning: Media, architecture, pedagogy. New York: Routledge.

Gaylie, V. (2009). The learning garden: Ecology, teaching, and transformation. New York: Peter Lang.

Gruenewald, D. A. \& Smith, G. A. (2008). (Eds.). Place-based education in the global age: Local diversity. New York: Lawrence Erlbaum Associates.

Grumet, M. (1988). Bitter Milk: Women and teaching. Amherst: University of Massachusetts Press.

Miller, J. R. (1996). Shingwauk's vision: history of native residential schools. Toronto: University of Toronto Press.

Oliver, M. (2005). New and Selected Poems: Volume Two. Boston: Beacon Press. Phillips, A. (1998). The beast in the nursery: On curiosity and other appetites. New 
York: Vintage Books.

Robinson, M. (1980). Housekeeping.Toronto: HarperCollings Publishers Ltd.

Subramaniam, M. A. (2002). Garden-based learning in basic education: A historical

review. Center for Youth Development, University of California. Retrieved

November 21, 2007

http://ucce.ucdavis.edu/freeform/4hcyd/documents/CYD_Monograph_(Focus)2609

.pdf

Weston, A. (1994). Back to earth: Tomorrow's environmentalism. Philadelphia: Temple University Press. 